\title{
Effect of Accruals Earnings Management on Share Price of Quoted Nigerian Firms
}

\author{
Ubesie Madubuko Cyril, Ogbu Samuel, Mbah Chris Chukwuemeka
}

Department of Accountancy, Enugu State University of Science and Technology, Enugu, Nigeria

\section{Email address:}

ubesiemadubuko@yahoo.com (U. M. Cyril)

\section{To cite this article:}

Ubesie Madubuko Cyril, Ogbu Samuel, Mbah Chris Chukwuemeka. Effect of Accruals Earnings Management on Share Price of Quoted Nigerian Firms. International Journal of Finance and Banking Research. Vol. 5, No. 4, 2019, pp. 105-113. doi: 10.11648/j.ijfbr.20190504.15

Received: March 27, 2019; Accepted: August 19, 2019; Published: September 2, 2019

\begin{abstract}
Earnings management occurs during which financial reports are prepared using judgment in order to mislead the stakeholders about the underlying economic performance of the company, or to influence contractual outcomes that are based on the reported earnings. This indicates that managements have incentives to manipulate the earnings in the purpose of maximizing the wealth of the company and/or the manager. This study employed the panel least squares while assuming fixed effects to test the effect of accrual-based earnings management on share prices of ten (10) sectors purposively sampled for twelve (12) years $(2006$ - 2017) and resulting in one hundred and fifteen (115) observations. The findings of DAA (Discretionary Adjustment Accrual) been positive and significant conforms with prior studies that distinguishes earnings management based on discretionary accruals. This suggests that discretionary accruals adjustment provides managers in Nigerian quoted firms the opportunities to manipulate earnings and hence share prices.
\end{abstract}

Keywords: Earnings Management, Share Price, Nigerian Firms, Accruals

\section{Introduction}

Earnings management is used to distort the true performance of firms. One of the managers' incentives to carry out these unethical practices could be to increase financial performance, which can only occur in the short term due to the fact that in the long term the market penalizes those manipulative companies and they enjoy lower corporate performance [1]. According to earnings management research, earnings releases of analysts reflect the earnings management practices, thus those companies that enjoy better earnings quality are associated with better and higher earnings releases [2] and it identifies a positive link between earnings quality and subsequent profitability. This result supports the previous evidence of Rangan (1998) which shows that initially the market overvalues and expects a higher return from companies that manipulate their outcome, but in the long-term their profitability and their corporate performance and corporate image is reduced by identifying such unethical practices [1]. So, when the market identifies unethical practices, it penalizes manipulative companies with subsequent poor stock price performance, etc. Thus, several researchers have considered that in financial reporting quality, companies with better financial reporting quality is associated with a decrease in information asymmetries, which affect corporate performance and stock prices by extension.

Jo and Kim (2007) analyse the link between information disclosure, earnings management (EM) and subsequent performance and obtain evidence of how higher levels of EM are associated with lower disclosure (and therefore a lower quality of the same) and lower future performance [3]. In the Nigerian corporate environment, the presence of and negative effect of earnings management on credibility of financial reporting and corporate failure has also been experienced [4]. A report of creative accounting scandal in African Petroleum PLC showed that the financial statements of the company did not fairly present the company's financial position [5]. In November 2006, an accounting scandal in Cadbury Nigeria Plc also raised more questions than answer about creative accounting [6]. Also, earnings management practice has been increasing in recent years in the Nigerian banking industry to attract unsuspecting investors, or obtain undeserved accounting-based rewards by presenting an exaggerated misleading or deceptive state of bank financial affairs [4].

When a financial statement reports by a company contain a 
greater volume of information quality; the trend towards earnings management is lower and the performance achieved by the company higher. This is consistent with the argument of $\mathrm{Tu}$ (2012) [7], that when information transparency is greater (one of the qualities required for better financial reporting quality), the tendency to manage earnings is lower. Earnings management is the inverse of financial reporting quality [8]; more earnings management is associated with lower quality of information and lower earnings quality. Following the definition of Healy and Wahlen (1999), earnings management occurs during which financial reports are prepared by using judgment in order to mislead the stakeholders about the underlying economic performance of the company, or to influence contractual outcomes that are based on the reported earnings [9]. This indicates that managements have incentives to manipulate the earnings in the purpose of maximizing the wealth of the company and/or the manager [10]. In this case, the financial results and position of the business might not be presented accurately. This may encourage fraud and material misstatement by the reporting entity. Since earnings management involves a higher degree of managerial judgment, this study concentrates on the negative aspect of earnings management. Jiraporn, Miller, Soon, and Young (2008) mentioned that distortions in financial reports occur when there is a misalignment of incentives between managers and shareholders [11]. This could drive the managers to exercise the flexibility of accruals accounting to adjust earnings opportunistically. Hence, accruals earnings management is employed in this study, and is considered the opportunistic behavior of the management. To this effect, this study examines the effect of earnings management on the share prices of Nigerian quoted firms. Following this introduction, the next section reviewed related literature. The methodology is explained in section three while sections four deals with the analysis and conclusion respectively.

\section{Literature Review}

\subsection{Conceptual Review}

\subsubsection{Earnings Management}

Earnings management is a strategy used by the management of a company to deliberately manipulate the company's earnings so that the figures match a predetermined target for the purpose of income smoothing [12]. Thus rather than having years of exceptionally good or bad earnings, companies will try to keep the figures relatively stable by adding and removing cash from reserves account [13]. Stolowy and Breton (2004) define earning management as the use of management's discretion to decide on accounting choices or to design transactions in a way that it will affect the chances of wealth transfer between the company and society, fund providers or managers [14]. Healy and Wahlen (1999) provide a comprehensive definition of earnings management to occur when managers use judgment in financial reporting and in structuring transactions to alter financial reports to either mislead some stakeholders about the underlying economic performance of the company or to influence contractual outcomes that depend on reported accounting numbers [9]. Fischer and Rosensweig (1995) define earnings management as actions by division managers which serve to increase (decrease) current reported earnings of a division without a corresponding increase (decrease) of the long-term economic profitability of the division [15]. As such, this definition identifies two important components of earnings management: consequences and intent [16].

Roychowdhury (2006) and Gajevszky (2014) argued that the manipulation of accounting figures as an outcome of ordinary operational practices appears to arise from management's motivation to mislead shareholders to ensure that the organization's financial targets have been met in the course of business. Due to the information asymmetry which exists between the company`s insiders and outsiders, individuals within an organization can rely on their control in financial reporting and their access to financial information within the company to overstate the income or to mask obtaining unfavorable results [16-18]. From this viewpoint, management many use different methods such as hiding the changes in economic performance by creating reserves for future periods, hence reducing income volatility [19, 20]. Earnings management is primarily accomplished through accounting transactions that are designed to achieve desired earnings level [4]. Prior research suggests that managers have both personal and business motivations to display impressive or at the very least satisfactory performance in their reports on a consistent basis [21]. However, due to a variety of reason, the sustainability of such a performance is sometimes impossible. Earnings management is the purposeful intervention in the external financial reporting process, with the intent of obtaining some private gain $[22,23]$.

\subsubsection{Incentives for Earnings Management}

Different incentives to manage earnings are widely discussed in the literature. Bhat (1996) linked it to the attempt to enhance shareholders' value and to maximize executive compensation through income smoothing and earnings management respectively [24]. Income smoothing, occasional big bath, living for today and maximization of variability are identified by Wall and Koch (2000) [25]. Chang, Shen\& Fang (2008) note three incentives to manage earnings [26]. Firstly, because of capital market motivation, which includes initial public offerings, seasoned equity offerings, management buoyant plans and plans for mergers to meet earnings forecast, to smooth earnings, etc. Secondly, contracts motivation such as management compensation, debt agreement or job security also constitute the incentive for earnings management. Thirdly, laws and regulations such as import regulation, industrial regulation, antitrust laws, e.t.c., also can serve as incentives. Cornett, McNutt \& Tehranian (2009) note that managers use discretionary accruals for opportunistic earnings management [27]. This includes options (the incentive for bonus income by attaining some level of performance) and affecting stock prices to 
enhance managers' wealth through restricted stock compensation.

Large and small firms engage in earnings management with different objectives. Kim, Liu and Rhee (2003) conducted a study to explore the relationship between earnings management and size of the firm and detected that small firms' main objective of smoothing income is to avoid reporting earning losses while large and medium sized firms engage in it more aggressively than the small firms with the objective of avoiding earnings decreases [28]. Kanagaretnam, Lobo, \& Robert (2004) suggest that the need for external financing, complying with regulatory capital requirement will act as motives for earnings management [29]. Beatty, Ke \& Petroni (2002) support the view of managers' smooth income to meet regulatory capital requirement. Other incentives include: bonus maximization, CEO turnover, insider trading, management buyouts, benchmark beating, equity offerings, mergers and stock-for-stock acquisitions, political costs, and debt covenant violations [30].

\subsubsection{Methodology of Earnings Management: Accruals Earnings Management}

Various methods for the detection of earnings management have been documented. Empirical studies have found managers engage in earnings management through changing accounting choice, real transactions, total accruals/discretionary accruals, specific accruals, earnings distributions approach and income smoothing [31]. This is since it is the most damaging to the usefulness of accounting information because investors are wary of such accruals [32]. By reviewing the past scholarly articles researchers have recognized several methods that are used to manage earnings [33]. Of all these methods, the total accruals approach seems to be the one that has caught the attention of researchers the most. A widely used model by many researchers is the Jones model or its modified versions. This model has been used in the literature to capture earnings management, which is viewed as an inverse measure of earnings quality [34-36].

Managers can opportunistically manipulate accounting reports by managing accruals. However, Kaplan (1985) states that "normal" accruals arising in the ordinary course of business are unlikely to reflect managerial opportunistic behavior [37]. Any manipulation of accounting information will most likely be apparent in "abnormal" accruals. The discretionary component of accruals adjustment could be used as a measurement of discretionary management, and therefore of accounting manipulation. As observed by Garcia-Osma, Gill de Albornoz Noguer and Gisbert Clemente (2005), accruals are not all discretionary; hence it is necessary to separate the discretionary component from the non-discretionary one to determine the presence and extent of earnings management and hence earnings quality [38]. Kothari, Leone and Wasley (2005) model uses the following procedure to separate the discretionary from the nondiscretionary accrual component [39]. The model proposed by Kothari et al. (2005) is characterised by the incorporation of a non-deflated constant and the return on assets, or financial profitability. All variables (except the constant) are deflated by the total assets for the previous period and are calculated by cross estimation. Dechow et al., (1995) examined various models to separate total accruals into normal and abnormal components [13]. They conclude that the Modified Jones Model is the most effective in identifying abnormal accruals that likely reflect earnings management.

\subsubsection{Share Price}

Share price is the cost of purchasing a security on an exchange [40]. It is affected by a number of things including volatility in the market, current economic conditions, and popularity of the company. Allen, Larson and Sloan (2010) argued that share price is not merely a reflection of accounting fundamentals but the combination of appropriate discount rate and the pattern of cash flow, make the stock market to decide the price (random walk theory) [41]. Subbramanyam and Wild (1996) assert that higher share price may signal that the company has a good product and induce consumers to adopt its product to start a positive feedback [42]. Ejuvbekpokpo and Edesiri (2014) posited that share prices serve as the basis for the assessment of whether a firm is breaking even or not [43]. According to Geetha, Ti and Swaaminathan (2015) stock market is an imperative part of the economy of a country. Its importance can be seen from both the industry's and investor's point of view [44]. These prices are relevant metrics of returns to stakeholders, and therefore the value attached to them matters so much to both existing and prospective investors in the capital market [43]. Generally, share price in an efficient market provides investors with a good measure of any firm's performance and its value [45].

\subsubsection{Theoretical Framework: Agency Theory}

Advanced by Fama \& Jensen (1976), this theory acknowledges that managers, standing in a privileged position of being the custodians of the company's information and being privy to better information of the company, can be reasonably expected to disseminate it to the principal and other users [46]. Contrary to the expectations of many, even though the company and its management choose accounting principles, the management out of intense self interest manipulates the process so that they may fail to disclose important information to the owners and other users. This can only attest to the norm that people often make choices that are motivated by individual's ambition and geared to the fulfillment of their own needs. One of the defining characteristics of business in the 1990s was the adoption of the Agency theory to address the managerial excesses of the 1970s and 1980s. The classical Agency concept was developed by Berle and Means (1932) who observed that ownership and control which have been separated in larger corporations because of dilution in equity positions provided an opportunity for professional managers to act in their own best interest [47]. Thus, the Agency theory attempted to provide explanation to firm behaviours in choice financing. The earlier works of Berle and Means (1932), Jensen and Meckling (1976) and Grossman and Hart (1982) 
are pioneer in Agency theory research [47-49]. Their analyses permitted the building up of interlink between the organization and the agency theory of corporate finance. Therefore, the Agency theory is a contractual device suggested to balance the motives of management and that of shareholders'.

\subsubsection{Market Efficiency Theory}

Fama (2011) defined efficient market as one which fully reflects all the available information, past, present and future in the asset prices [50]. According to Basu (2007), in an efficient capital market, security prices fully reflect available information in a rapid and unbiased fashion and thus provide unbiased estimates of underlying values [51]. There are three forms of market efficiency, namely weak form market efficiency, semi-strong form market efficiency and strong form market efficiency. Weak form market efficiency assumes that current stock prices reflect all the past information available including historical sequence of price, rates of return, trading volume and market generated information. This implies that future share prices cannot be forecasted using past rates of return. The semi-strong form market efficiency argues that the current prices of stock reflect all the available information content of historical prices and the publicly available information about corporations. This implies that information is quickly impounded in the share prices as they become available. The investors who base their decisions on new information cannot make above average profit after the information is made. The strong form suggests that security prices reflect the available information and even private information. No group of participants has monopolistic access to the relevant information hence, no one makes above average profits. Seyton (2013) provides sufficient evidence that insiders profit from trading on information not already incorporated into prices hence, the strong form does not hold in a world of an even playing field [52]. While there is substantial empirical evidence supporting the efficient market hypothesis, many still question its validity [53]. Market efficiency theory seeks to understand the behaviour of a firm by analysing historical sequence of price, rates of return, trading volume and market generated information. This theory offers an insight to the management and shareholders about the performance of the company.

\subsection{Empirical Review}

Sayari (2018) examined the effect of earnings management on stocks liquidity using two modified earnings management measurement models: modified model of Jones (1995) and model of Kothari et al. (2005). Using a panel data qualitative approach, the obtained results point to a positive relationship between discretionary accruals and Tunisian firms' ask-bid spread (as estimated by the two measurement models). This indicates that discretionary accruals allow Tunisian investors to optimally construct their stocks portfolios. The collected results also highlighted a negative and a significant impact of transaction size and volume on firms' ask-bid spread. Indeed, earnings management allows for increasing stocks liquidity when discretionary accruals are negative and reducing their liquidity when these accruals are positive $[54,55]$. This is confirmed by the two discretionary accruals models.

Ching, et al (2015) investigated the relationship among audit quality, earnings management, and financial performance among public listed companies in Malaysia [10]. Sampled companies were randomly selected from the Industrial Products and Consumer Products industry listed on the Main Board of Bursa Malaysia during the time period of 2008 to 2013 while using the multiple regression model to test the relationship among the variables. The findings indicate that audit quality does not actually constrain earnings management practices in Industrial Products and Consumer Products companies. This may be due to the difference between the audit environment in Malaysia and that in other developed countries. On the other hand, high audit quality can contribute to better company financial performance, since large-scale audit firms are always perceived to have higher audit quality that can increase the confidence of investors.

Oraby (2017) investigated the impact of earnings management strategies on accounting information relevance with the application to listed companies in Saudi stock exchange during the period from 2012 to 2016 using the balanced panel data methodology with a sample of 113 companies [56]. Regression analysis that accounting accrualbased earnings management strategy is used to manipulate earnings downward but it is not of value relevance because it has no effects on share prices. On the other hand, real activities-based earnings management strategy is statistically significant and of value relevance and it is used to manipulate net income upward.

Sayari, Mraihi, Finet \& Omri (2013) presented and compared four earnings management measurement models examining Tunisian stock market information content and the ability to forecast managers' behavior [57]. We classified the variable "discretionary accruals" into higher and lower levels and then analysed its effect on returns. The obtained results point to a significant coefficient for the two levels of discretionary accruals (according to the four models).

Arar, Al-Sheikh \& Hardan (2018) examined the relationship between earning's management and the stock price liquidity for a selected sample of (49) Jordanian Service Companies listed on Amman stock market for the period of (2010-2015) [58]. Using the Jones Modified Model (1995), the outcomes of this study indicated a non-significant relationship between the Earning's Management and the Stock Price Liquidity in The Jordanian Service Companies.

Akram, Hunjra, Butt and Ijaz (2015) elaborated on the impact of earnings management on the organizational performance of construction and material firms in Pakistan and India [59]. The sample of this study was 20 listed companies of Karachi Stock Exchange (Pakistan) and 20 of Bombay Stock Exchange (India) for the period of 2009-2013. OLS technique was applied for hypothesis testing. The study indicates a significant negative relationship between earnings 
management and organizational performance in Pakistan. On the other hand, there is an insignificant relationship between earnings management and organizational performance in India.

Altintaş, Sari and Otluoğlu (2017) analyzes the presence of earnings management practices by using financial information of the Turkish listed manufacturing companies [60]. Findings from the regression results display that low performance companies tend to increase their earnings so that they can hide their low performance. Other results point out that there is significant and positive relationship between earnings and market adjusted stock returns for whole sample, however there is no significant difference between adjusted market returns of high and low performance companies.

Amadi and Amadi (2016) investigated the variability of real business activities in the form of discretionary expenditures (accounts receivable, selling, general and administrative expenses, and net change in accruals), and the firm's stock price performance in relation to the frequency of meeting or beating analysts' earnings forecast [61]. In addition, the study investigated the relationship between the firm's stock price performance, and the variability of these financial statement accounts. The study found that there is a significant difference between the variance of SG \& A, NCA and stock returns of the firms that meet and/or beat the analysts' forecast and those that do not. It was also found that there is a significant difference in stock returns based on meeting and/or beating the analysts' estimate.

Martínez-Ferrero (2014) examined the consequences of Financial Reporting Quality (FRQ) on Corporate Performance, using three proxies of FRQ: (i) earnings quality; (ii) conservatism; and (iii) accruals quality. Our purpose is to analyze the effect of a good FRQ on financial performance (FP) measured by the market to book ratio [62]. To this end, the proposed hypotheses are tested on an unbalanced sample of 1, 960 international non-financial listed companies from 25 countries and the special administrative region of HongKong for the period 2002-2010. The result supports a positive relationship, since a higher level of BALLSHIVAKUMAR represents a lower level of accruals quality and consequently, a lower level of financial performance. Thus, accruals quality impacts positively on financial performance, thereby companies which report poor quality financial information have better market to book ratio as a financial performance measure.

On earnings management and share price, literature abound on accruals measurement for earnings management. Teoh, Welch and Wong (1998) documented that discretionary current accruals grow before the offering, peak in the offering year, and decline thereafter [63]. Rangan (1998) confirmed this finding using quarterly accruals [1]. Among the four accrual measures, discretionary (i.e. managed) current accruals were shown to predict subsequent poor share price performance. Ducharme, Malatesta and Sefcik (2004) found that firms in the period around share offer report abnormal accrual components in their earnings
[64]. However, in the period after the share offerings, the abnormal accruals are negatively related to the returns or even they tend to reverse in the post offer period. Marquardt and Wieldman (2004) notes that earlier research has shown that firms manage earnings upward prior to initial offerings and seasoned equity offerings in order to increase the market price of the share [65].

Lee, Li and Yue (2006) examined a popular belief that managers of high valuation companies have a stronger incentive to manipulate future earnings than low valuation companies and found the belief to be only half true by concluding that a positive relationship between valuation and future discretionary accruals only exists for companies receiving limited attention [66]. Zaluki (2008) found strong evidence of declining performance in the IPO year and up to three years following IPOs relative to the pre-IPO period [67]. Ekoja (2004) employed a regression analysis following Jeter and Shivakumar (1999)'s cash flow model and found that there is evidence that earnings management exist in the banks on a cross sectional basis $[68,69]$. Jones (1991) relaxed the assumption of non-discretionary accruals not changing across periods by considering the effects of changes in a company's economic circumstances such as changes in revenues and changes in property plant and equipment/ in the model [70]. The finding, which is consistent with the earnings management hypothesis, showed that managers make use of income decreasing accruals during import relief investigation. The main problem with the Jones (1991) model is the inclusion of "change in revenue" variable to estimation of non-discretionary accruals. In case of revenue manipulation, the model will be inappropriate because the nondiscretionary accruals are estimated from manipulated data. In addition, to avoid the shortcomings of Jones (1991), Dechow, Sloan and Sweeney (1995) suggested a new model, often referred as the Modified Jones Model, which uses only cash sales instead of total revenue in the calculation of the change in revenue variable [13]. They argued that the modified Jones Model is the most helpful model to detect earnings management, but Bernard and Skinner (1996) argued that discretionary accruals estimated using Jones and Modified Jones Models reflect measurement error due in part to the systematic misclassification of non-discretionary accruals as discretionary accruals [71].

Erickson and Wang (1999) analyzed firms using share as a mode of payment in acquisitions. Erickson and Wang (1999) hypothesize that such bidders will manage earnings upwards via discretionary accruals in an attempt to increase the share price and thereby decrease the number of shares that must be issued to complete the deal [72]. They find evidence consistent with their expectations: bidders relying on share as consideration manage earnings upward as measured with abnormal accruals whereas bidders in non-share deals do not. DeFond and Park (1997) presented evidence that when current earnings are poor and expected future earnings are good, managers, motivated by concerns over job security, borrow earnings from the future for use in the current period (and vice versa) [73]. 
Aref, Ardekani and Mohammad (2012) examined the relationship between earnings management and performance of acquiring firms in Malaysia during the period 2004-2010 [74]. The study measured earnings management using discretionary accruals derived from modified Jones model and firm's performance estimated by monthly Cumulative Abnormal Return (CAR). The results indicated that share acquirer firms unlike cash acquirers manipulated their earnings preceding acquisition announcement date.

\subsection{Research Gap}

On earnings management and share price, literature abound on accruals measurement for earnings management but are older literatures without inputs from a developing country perspective. In addition, Bernard and Skinner (1996) argued that discretionary accruals estimated using Jones and Modified Jones Models reflect measurement error due in part to the systematic misclassification of non-discretionary accruals as discretionary accruals [71]. Thus to avoid the shortcomings of Jones and Modified Jones Models (1991) this study employed the Martinez-Ferrero (2014) model of estimating accruals [62]. This model provides increased reliability and higher quality results, by resolving the question of whether differences in discretionary accrual adjustment DAA may derive from differences in performance [62]. Thus, there is the need for the subject of accruals earnings management and it's consequences on share price to be reviewed in the Nigerian context. This forms the basis for the study.

\section{Methodology}

In executing this study, the ex-post facto research design was adopted. The nature of the data is secondary data and sourced from the published audited financial statements and accounts of firms quoted on the Nigeria Stock Exchange (NSE). Although there exist twelve (12) industrial classifications on the NSE only ten (10) sectors were purposively sampled for twelve (12) years (2006 - 2017). Due to the choice of variables adapted from Martinez-Ferrero (2014) as detailed in section two, the financial services industry was not sampled. Again, there are no firms recorded under the Utilities sector. The study employed the panel least squares while assuming fixed effects to test the effect of accrual-based earnings management on share prices of quoted firms in Nigeria.

The model for the study is structured thus:

$$
\mathrm{SP}_{\mathrm{it}}=\mathrm{NDAA}_{\mathrm{it}}+\mathrm{DAA}_{\mathrm{it}}+\mathrm{TAA}_{\mathrm{it}}+h_{\mathrm{it}}+\varepsilon_{\mathrm{it}}
$$

Where:

$\mathrm{SP}_{\text {it }}=$ Share Price of Firm $i$ at time $t$. This is year ending market prices of the sampled firms. The independent variables in this model provides increased reliability and higher quality results, by resolving the question of whether differences in discretionary accrual adjustment DAA may derive from differences in performance (Martínez-Ferrero, 2014). This is derived as follows:

$$
\mathrm{TAA}=\frac{1}{\text { Ait }}+\frac{\Delta \text { SALESit }- \text { ARit }}{\text { Ait }}+\frac{\text { PPEit }}{\text { Ait }}+\frac{\text { ROAit }}{\text { Ait }}+E t
$$

Where TAA = the total accrual adjustments;

$\mathrm{A} i t=$ total assets of firm $\mathrm{i}$ in period $\mathrm{t}-1$ and this is used as a deflator to correct possible problems of heteroskedasticity;

PPEit = the property, plant and equipment of firm $\mathrm{i}$ in period t;

$\triangle$ SALESit $=$ change in sales for firm $\mathrm{i}$ in period $\mathrm{t}$;

ARit $=$ Accounts receivable for firm $\mathrm{i}$ in period $\mathrm{t}$ and;

ROAit $=$ the return on assets for firm $\mathrm{i}$ in period $\mathrm{t}$.

$$
\mathrm{NDAA}=\frac{1}{A i t}+\frac{\Delta S A L E S i t}{A i t}+\frac{P P E i t}{A i t}+\frac{R O A i t}{A i t}+E t
$$

Where: NDAA $=$ Non-discretionary Accrual Adjustments

$\mathrm{A} i t=$ total assets of firm $\mathrm{i}$ in period $\mathrm{t}-1$ and this is used as a deflator to correct possible problems of heteroskedasticity;

PPEit $=$ the property, plant and equipment of firm $\mathrm{i}$ in period t;

$\triangle$ SALESit $=$ change in sales for firm $\mathrm{i}$ in period $\mathrm{t}$;

ROA $i t=$ the return on assets for firm $\mathrm{i}$ in period $\mathrm{t}$.

Thus, TAA - NDAA = DAA (Discretionary Adjustment Accrual) and are the residuals of this calculation.

\section{Findings}

This study hypothesized that accruals earnings management do not have a significant effect on the share prices of quoted firms in Nigeria. Accruals earning management is disintegrated into total accrual adjustment (TAA), non-discretionary accrual adjustment (NDAA) and discretionary accrual adjustment (DAA). Table 1 presents the panel least squares of the test of the model.

Table 1. Panel least squares of Equation 1.

\begin{tabular}{ll}
\hline Dependent Variable & STOCK_PRICE \\
\hline Method & Panel Least Squares \\
Date & $03 / 25 / 19$ \\
Time & $08: 23$ \\
Sample & 20052017 \\
Periods included & 13 \\
Cross-sections included & 10 \\
Total panel (unbalanced) observations & 115 \\
White diagonal standard errors \& covariance (d. f. corrected) & \\
\hline
\end{tabular}




\begin{tabular}{lllll}
\hline Variable & Coefficient & Std. Error & t-Statistic & Prob. \\
\hline TAA & -5.163005 & 15.91441 & -0.324423 & 0.7464 \\
NDAA & -7.694293 & 4.949224 & -1.554646 & 0.1235 \\
DAA & 9.416572 & 4.776699 & 1.971356 & 0.0517 \\
C & 38.29901 & 3.450581 & 11.09929 & 0.0000 \\
\hline
\end{tabular}

\begin{tabular}{|c|c|c|c|}
\hline \multicolumn{4}{|c|}{ Effects Specification } \\
\hline \multicolumn{4}{|c|}{ Cross-section fixed (dummy variables) } \\
\hline \multicolumn{4}{|c|}{ Period fixed (dummy variables) } \\
\hline R-squared & 0.813620 & Mean dependent var & 32.36165 \\
\hline Adjusted R-squared & 0.766513 & S. D. dependent var & 51.59840 \\
\hline S. E. of regression & 24.93262 & Akaike info criterion & 9.453550 \\
\hline Sum squared resid & 56568.85 & Schwarz criterion & 10.02641 \\
\hline Log likelihood & -519.5791 & Hannan-Quinn criter. & 9.686069 \\
\hline F-statistic & 17.27169 & Durbin-Watson stat & 1.741950 \\
\hline Prob (F-statistic) & 0.000000 & & \\
\hline
\end{tabular}

Source: Author's Eviews 9.5 Output.

Table 1 shows that the t-Statistics of total accrual adjustment (TAA), non-discretionary accrual adjustment (NDAA) and discretionary accrual adjustment (DAA) stood at $-0.3244,-1.5546$ and 1.9713 respectively. The probability of the t-Statistics was not significant for TAA and NDAA while been significant at $10 \%$ for DAA. It is noteworthy that DAA (Discretionary Adjustment Accrual) are the residuals of the calculation arrived at adjustment (TAA) less nondiscretionary accrual adjustment (NDAA).

\section{Conclusion}

Since earnings management involves a higher degree of managerial judgment, this study concentrates on the negative aspect of earnings management. Distortions in financial reports occur when there is a misalignment of incentives between managers and shareholders. This could drive the managers to exercise the flexibility of accruals accounting to adjust earnings opportunistically. Hence, accruals earnings management is employed in this study, and is considered the opportunistic behavior of the management. To this effect, this study examines the effect of earnings management on the share prices of Nigerian quoted firms. The findings of DAA (Discretionary Adjustment Accrual) been positive and significant conforms with prior studies that distinguishes earnings management based on discretionary accruals. This suggests that discretionary accruals adjustment provides managers in Nigerian quoted firms the opportunities to manipulate earnings and hence share prices.

\section{References}

[1] Rangan, S. (1998). Earnings management and the performance of seasoned equity offerings. Journal of Financial Economics, 50, 101-122

[2] Louis, H. (2004). Earnings management and the market performance of acquiringfirms. Journal of Financial Economics 74, 121-148.
[3] Jo, H. and Kim, Y. (2007). Disclosure frequency and earnings management. Journal of Financial Economics, 84, 561-590.

[4] Atu, O. O. K., Atu, F. O., Enegbe, O. P. and Atu, E. C. (2016). Determinants of earnings management in Nigerian quoted companies. Igbinedion University Journal of Accounting, 1 (February); 118-133.

[5] Oyejide T. A., Soyibo. A. (2001). Corporate Governance in Nigeria Journal of Business Ethics. 82 (1), 119-130.

[6] Itsueli, U. I. (2006). Public statement: Cadbury Nigeria Plc. Retrieved from www.nse.com on $19^{\text {th }}$ December, 2015.

[7] Tu, C. J. (2012). the impact of stocks index adjustments announcement on earnings management. International Journal of Economics and Finance, 4 (11): 91-98.

[8] Dechow, P. and Dichev, I. (2002). The quality of accruals and earnings: The role of accrual estimation errors, The Accounting Review, 77 (Supplement): 35-59.

[9] Healy, P. and Wahlen, J. (1999). A review of the earnings managment literature and its implications for standard settings. Accounting Horizons, 13 (4), 365-383.

[10] Ching, C. P., Teh, B. N., San, O. T. and Hoe, H. Y. (2015). The Relationship among audit quality, earnings management, and financial performance of Malaysian public listed companies. Int. Journal of Economics and Management, 9 (1): 211-229.

[11] Jiraporn, P., Miller, G. A., Soon, S. Y., and Young, S. K. (2008). Is earnings management opportunistic or beneficial? An agency theory perspective. International Review of Financial Analysis, 17, 622-634.

[12] Iraya, C., Mwangi, M. and Muchoki, G. W. (2015). The effect of corporate governance practices on earnings management of companies listed at the Nairobi securities exchange. European Scientific Journal, 11 (1): 169-178.

[13] Dechow, P. M., Sloan, R. G. \& Sweeney, A. P. (1995). Detecting earnings management. The accounting Review 70, 193-225.

[14] Stolowy, H. and Bretton, G. (2004). Accounts manipulation: A literature review and proposed conceptual framework. Review of Accounting and Finance, 3 (1), 5-66. 
[15] Fischer, M. \& Rosenzweig, K. (1995). Attitudes of students and accounting practitioners concerning the ethical acceptability of earnings management. Journal of business ethics, 13, 205-221.

[16] Abbadi, S. S., Hijazi, Q. F. and Al-Rahahleh, A. S. (2016). Corporate governance quality and earnings management: evidence from Jordan. Australasian Accounting, Business and Finance Journal, 10 (2); 54-75.

[17] Roychowdhury, S. (2006). Earnings management through real activities manipulation. Journal of Accounting and Economics, 42 (3), 335-370.

[18] Gajevszky, A. (2014). The impact of auditor's opinion on earnings management: evidence from Romania. Network Intelligence Studies, 3, 61-73.

[19] Leuz, C., Nanda, D. and Wysocki, P. (2003). Earnings management and investor protection: An international comparison. Journal of Financial Economics, 69 (3), 505527. Martínez-Ferrero, J. (2014). Consequences of financial reporting quality on corporate performance. Evidence at the international level. Estudios de Economía, 41 (1); 49-88.

[20] Hijazi, Q. \& Al-Thuneibat, A. (2015). Auditor's opinions and earnings management: evidence from Jordan, Proceedings of The Third International Conference on Innovation Economy, University of Jordan, Amman, Jordan, 14-15 April.

[21] Green field, A. C., Carolyn Strand Norman, \& Benson Wier, (2008). The effect of ethical orientation and professional commitment on earnings management behavior. Journal of Business Ethics, (83) 419-43.

[22] Schipper, K. (1989). Commentary on earnings management. Accounting Horizon 3 (1). 91-102.

[23] Tasios, S. and Bekiaris, M. (2012). Auditor's perceptions of financial reporting quality: the case of Greece. International Journal of Accounting and Financial Reporting, 2 (1): 54-74.

[24] Bhat, V. N. (1996). Banks and income smoothing: an empirical analysis. Applied Financial Economics.

[25] Wall, L. D. and Koch, T. W. (2000). The Use of accruals to manage reported earnings: theory and evidence. Working Paper Series, Federal Reserve Bank of Atlanta.

[26] Chang, R. D., Shen, W. H. \& Fang, C. J. (2008). discretionary loan loss provisions and earnings management for the banking industry. International Business \& Economics Research Journal, 7 (3); 9-20.

[27] Cornett, M. M., McNutt, A. J. \& Tehranian, H. (2009). Corporate governance and earnings management at large U.S. banks holding companies. Journal of Corporate Finance, 15: 412-430.

[28] Kim, Y., Liu, C., \& Rhee, S. G. (2003). The effect of firm size on earnings management. NIBER Working paper no. 25.

[29] Kanagaretnam, K., Lobo, G. J., \& Mathieu, R. (2003). managerial incentives for income smoothing through bank LLP. Review of Quantitative Finance and Accounting, 45; 6380 .

[30] Beatty, A. L., Ke, B., \& Petroni, K. R. (2002). Earnings management to avoid earnings declines across publicly and privately held banks. The Accounting Review, 45; 547-570.
[31] Sun, L. and Rath, S. (2011). The effect of firm performance on modeling discretionary accruals: an evaluation of accrual models. Proceedings of Macao International Symposium on Accounting and Finance.

[32] Al-Fayoumi, N., Abuzayed, B. \&Alexander (2010): Ownership structure and earnings management in emerging markets: the case of Jordan. International Journal of Finance and Economics, (38), 28-47.

[33] Fernando, W. D. I. \& Ekanayake, E. M. N. N. (2015). Do commercial banks use loan loss provisions to smooth their income? empirical evidence from Sri Lankan commercial banks. Journal of Finance and Bank Management, 3 (1); 167179 .

[34] Bartov, E., Gul, F. \&Tsui, J. (2001), Discretionary - accruals models and audit qualifications. Journal of Accounting and Economics, 30 (3); 421-452.

[35] Gul, F., Chen, C. and Tsui, J. 2003, Discretionary accounting accruals, managers' incentives and audit fees. Contemporary Accounting Research, 20 (3); 441-464.

[36] Dowdell, T. and Krishnan, J. (2004). Former audit firm personnel as CFOs: Effect on earnings management. Canadian Accounting Perspectives, 3 (1); 117-142.

[37] Kaplan, R. S. (1985). Comments on Paul Healy: Evidence on the effect of bonus schemes onaccounting procedure and accrual decisions. Journal of Accounting and Economics 7: 109-113.

[38] García Osma, B., Gill de AlbornozNoguer, B. \& Gisbert Clemente, A. (2005). La investigaciónsobre" earnings managements. Revista Española de Financiación y Contabilidad, XXXIV (127), 1001-1034.

[39] Kothari, S., Leone, A., \&Wasley, C. (2005). Performance matched discretionary accrual measures. Journal of Accounting and Economics, 39 (1), 163-197.

[40] Ibrahim, S. (2010). An analysis ofthe capital market operatorsin Nigeria. International Journal of International Law, 2 (2), 1-26.

[41] Allen, E., Larson C. \& Sloan, R. (2010). Accrual reversal, earnings and stock returns. The Accounting Review, 65 (1): 49-71.

[42] Subramanyam, K. R., \& Wild, J. (1996). Going concern status, earnings persistence, and informativeness of earnings. Contemporary Accounting Research, 13: 251273.

[43] Ejuvbekpokpo A. S. \& Edesiri, G. O. (2014). Determinants of stock price movement in Nigeria: (evidence from the Nigerian stock exchange). Journal of Economics and Sustainable Development, 5 (3): 1-7.

[44] Geetha, E. \& Ti. S. M. (2015). A study on the factors influencing stock price, A comparative study of automobile and information technology industries stocks in India. International Journal Current Research and Academic Review, 3 (3): 97-109.

[45] Olawale, S. A. \& Olaniyi K. L. (2015). Equity share price determinants: a survey of literature, Arabian Journal of Business and Management Review, 5 (3), 38-54.

[46] Fama, E. \& Jensen, M. (1983). Agency problems and residual claims. Journal of law and Economics, 26 (2), 327-349. 
[47] Berle, A., \& Means, G. (1932). The modern corporation and private property. New York, NY: Macmillan.

[48] Jensen, M. C. and Meckling, M. H. (1976). A theory of the firm: Governance, residual claims and organizational forms.Journal of Financial Economics, 3 (4), 305-360.

[49] Grossman, S., \& Hart, O. (1983). An analysis of the principalagent problem. Econometrica, 51 (1), 7-45.

[50] Fama, E. (2011). Efficient capital markets. Journal of Finance, 46: $1575-1617$

[51] Basu, S. (2007). Investment performance of common stocks in relation to their price - earnings ratios: A test of the efficient market hypothesis. The Journal of Finance, 32 (3); 663-682.

[52] Seyton, N. (2013). Insiders profits, costs of trading and market efficiency. Journal of Financial Economics 16: 189-212.

[53] Ali shah, S. Z., Butt, S. A. and Hasan, A. (2009). Corporate governance and earnings management an empirical evidence form Pakistani listed companies. European Journal of Scientific Research, 26 (4): 624-638.

[54] Sayari, S. (2018). Investigation of the effect of earnings management on stock liquidity for the case of the Tunisian Stock Exchange. International Journal of Accounting and Taxation, 6 (1); 52-73.

[55] Jones, J. J. (1991). Earnings management during import relief investigations. Journal of Accounting Research, 29 (2), 193228 .

[56] Oraby, S. A. (2017). The impact of earnings management strategies on accounting information relevance. International Journal of Business and Social Science, 8 (4); 125-135.

[57] Sayari, S., Mraihi, F., Finet, A. \& Omri, A. (2013). The impact of earnings management on stock returns: the case of Tunisian firms. Global Journal of Management and Business Research, 13 (10); 50-66.

[58] Arar, S. S., Al-Sheikh, E. A. \&Hardan, A. S. (2018). The relationship between earnings management and stock price liquidity. International Journal of Business and Management, 13 (4); 99-107.

[59] Akram, M. A., Hunjra, A. I., Butt, S. and Ijaz, I. (2015). Earnings management and organizational performance: Pakistan VS India. Basic Research Journal of Business Management and Accounts, 4 (9); 211-220.

[60] Altintaş, A. T., Sari, E. S. and Otluoğlu, E. (2017). The impact of earnings management on the value relevance of earnings: empirical evidence from Turkey. The Journal of International Social Research, 10 (5); 885-889.

[61] Amadi F. Y. and Amadi, C. W. (2016). Earnings management and stock market returns. International Journal of Business, Economics and Management, 1 (10); 272-290.

[62] Martinez-Ferrero, (2014). Consequences of financial reporting quality on corporate performance. Evidence at the international level. Estudios de Economía, 41 (1), 49-88.
[63] Teoh, S., Welch, I. \& Wong, T. (1998). Earnings management and the long run underperformance of seasoned equity offerings. Journal of Financial Economics 50, 53-100.

[64] Ducharme, L. L., Malatesta P. H. \& Sefcik, S. E. (2004). Earnings management, stock issues and shareholder lawsuits. Journal of Financial Economics, 71, 27-49.

[65] Marquardt, C. A. \& Wiedman, C. I. (2004). How are earnings managed? An examination of losses and the behavior of security prices. Journal of Accounting and Economics, 22.

[66] Lee, C., Li, L. \& Yue, H. (2006). Performance, growth and earnings management. Review of Accounting Studies 11, 305334.

[67] Zaluki, N. A. A. (2008). Post-IPO operating performance and earnings management. International Business Research.

[68] Ekoja B. E. (2004). A cross-sectional analysis of discretionary accruals. Nigerian Journal of Accounting Research, 2, 36-44.

[69] Jeter, D. C. and Shivakumar, L., (1999). Cross-sectional estimation of abnormal accruals using quarterly and annual data. Effectiveness in detecting event-specific earnings management. Accounting and Business Research, 29 (4), 299319 .

[70] Jones, J. (1991). Earnings management during import relief investigations. Journal of Accounting Research 29, 193-228.

[71] Bernard, V. L. and Shimer, D. J. (1996). What motivates managers' choice of discretionary accruals? Journal of Accounting and Economics, 22, 313-325.

[72] Erickson, M. \& Wang, S. (1999). Earnings management by acquiring firms in stock for stock mergers. Journal of Accounting and Economics, 27, 149-176.

[73] DeFond, M. L., \& Park, C. W. (1997). Smoothing income in anticipation of future earnings. Journal of Accounting and Economics, 23 (2): 115-139.

[74] Aref, M., Ardekani, N. Y. \& Mohammad H. (2012). Acquisition, earnings management and firm's performance: evidence from Malaysia. Journal of Business Studies Quarterly, 4 (1), 91-110.

[75] Ajina, A., Lakhal, F. and Sougné, D. (2015). Institutional investors, information asymmetry and stock market liquidity in France. International Journal of Managerial Finance, 11 (1): 44-59.

[76] Attig, N., Wai-Ming, F., Yoser, G., and Larry, H. P. L. (2006). Effects of large shareholding on information asymmetry and stock liquidity. Journal of Banking \& Finance, 30 (10): 287592.

[77] Ascioglu, A., Hegde, S. P., Krishnan, G. V. and McDermott, J. B. (2012). Earnings management and market liquidity. Review of Quantitative Finance and Accounting, 38 (2): 257-74.

[78] Brockman, P. and Chung, D. Y. (2001). Managerial timing and corporate liquidity: evidence from actual share repurchases. Journal of Financial Economics 61 (3): 417-48. 